\title{
EFL Curriculum Design: The Case of the Greek State School Reality in the Last Two Decades (1997-2014)
}

\author{
Alexandra Anastasiadou \\ 65 Georgikis Sholis Avenue, 57001 Thessaloniki, Greece \\ and Hellenic Open University \\ 18 Parodos Aristotelous, 26335 Patras, Greece \\ E-mail: dhm3kat@yahoo.gr
}

Received: 16-08-2014

Accepted: 16-10-2014

Published: 01-03-2015

doi:10.7575/aiac.ijalel.v.4n.2p.112

URL: http://dx.doi.org/10.7575/aiac.ijalel.v.4n.2p.112

\begin{abstract}
This paper will delve into the last three versions of curriculum for the teaching of English in the Greek state school in the last seventeen years (1997- 2014). More specifically, an analysis of these three curriculums was carried out with a view to tracing similarities and differences and exploring the incorporation of contemporary methodological and pedagogical approaches or lack thereof. The results reveal evidence of similarities such as smooth integration of new information to the students' stored knowledge and differences namely the application of differentiated instruction among these three documents which are indicative of the gradual social and pedagogical changes both worldwide and locally. The connection between the layout of the curricula is substantiated and tentative suggestions are provided for ameliorating their content and aims so as to render them more accessible to learners' needs.
\end{abstract}

Keywords: L2 English curriculum design, curriculum development, educational innovation, methodological and pedagogical approaches to teaching foreign languages, Greek educational reality

\section{Introduction}

As the aim of the present article is to compare and contrast the three last curricula for teaching English as a foreign language in the Greek educational context, it was deemed crucial to determine a clear definition of the terms "curriculum" and "syllabus", as various theorists (Brumfit, 1984; White, 1988; Nunan, 1989; Pantaleoni, 1991) have put forward diverse definitions. Brumfit (1984, p. 75) limits the term "syllabus" to the responsibility of the language teacher, with curriculum signifying the total provision within a teaching institution. Both White $(1988$, p. 4) and Nunan (1989, p. 14) claim that syllabus contains the content of an individual subject, while curriculum communicates the totality of content to be taught and aims to be achieved in an educational programme. In an effort to better clarify the dissimilarity between curriculum and syllabus, Pantaleoni (1991, p. 302) contends that the former unravels broad institutional and classroom aims, while the latter is a more day-to-day, locally-specific guide for the teacher. Such a guide focuses on "what" should be taught and learnt, rationalising simultaneously "how" this content must be chosen and sequenced. This attitude, which regards syllabus as subordinate to curriculum will be followed in the present paper. More specifically, language curriculum refers to all the issues relevant to the "planning, implementation and evaluation of a series of language learning events conceived as a coherent whole with a specified purpose" (Hall \& Hewings, 2001, p. 1).

In this vein, a national curriculum is the umbrella framework which embraces the content, the aims and the methodology of the totality of knowledge provided to pupils in the primary and secondary schools. The contemporary methodological, pedagogical and social dimensions comprise the backbone of the design of a curriculum.

Having clarified the term "curriculum", the next section will focus on the methodological dimensions and administrative directives applied for its organisation.

\section{Ways of Organising the Curriculum}

\subsection{General Theoretical and Methodological Considerations}

\subsubsection{The Communicative Approach}

In the late 1970s emphasis was put on the communicative aspect of teaching and learning foreign languages. This communicative orientation was congruent with Widdowson's (1978, p. 3) tenet about "usage" and "use", whereby "usage" is the demonstration of correct knowledge of the linguistic system and "use" is the appropriate capitalisation of the particular knowledge for a communicative goal. Thus, the most important contribution of the Communicative Approach was the fact that it placed equal emphasis on both the functional and organisational dimensions of language provided that meaning is transmitted and communication is fulfilled.

As a result, the design of language curriculla started to be aligned with the communicative paradigm. The communicative curriculum incorporates not only what the structures mean but also how to best use them in real-life 
situations. Moreover, it clearly indicates how students can apply functions and notions, and at the same time develop strategies through language (Swan, 1985).

Although, the Communicative Approach has prevailed since the 1970s, several investigators (Prabbu, 1990; Richards, 1990; Kumaravadivelu, 1994) have questioned the significance of one prevailing method and even supported the demise of methods, pinpointing that no method can be regarded as dominant (Brown, 2002). Consequently, ever since the notion of searching the best method has been discredited (Prabbu, 1990), a new tendency has arisen (Bell, 2007) reflecting the teachers'interest in being offered a variety of approaches in order to accommodate their teaching context in relevance to the communicative orientation and the emerging methodological and pedagogical trends. This tenet necessitates the compliance of curriculum reconceptualisation and design to the recent methods and tendencies of each era.

\subsubsection{Learner-centeredness - Fostering Autonomy in Learning}

The student-centered paradigm (Nunan, 1988) places the students' needs and development in the core of an educational system. Therefore, the curriculum should cater for the linguistic, cognitive, emotional and social evolution of the learners by taking into consideration their preferences and promoting critical thinking, self-discovery of knowledge as well as group work. Students are orientated to solve problems, take decisions, participate actively in their own learning through assessing whether both the process and the product of their learning has materialised their prearranged objectives.

The optimal evidence of a learner-centered curriculum is the use of experiential learning (Nunan, 2004). This approach assumes that the students' experience is the onset of the learning process. Students evolve intellectually and cognitively when they are actively involved in activities. Therefore, the focal point of experiential learning is the notion of "learning by doing", which regards learners as active processors of knowledge rather than passive receivers of information from the teacher.

Seen in this light, learners are trained to "learn how to learn" (Williams, 1991, p. 206) which is a key element in a curriculum which aspires to foster learner autonomy by rendering the students responsible of their own learning process. Little by little learners are educated to build their learning and reasoning and simultaneously expand their "metacognition" (Bruner, 1988, p. 265) that is advance their ability to think about their own learning and thinking.

\subsubsection{The Multiple Intelligences framework}

The way students think and learn bears high relevance to the notion of intelligence. Gardner (1983, 1999) contradicted the long-held theory that attributed a unified trait to the human intelligence arguing that there are eight types of intelligence and all people possess a blending of these types of intelligences.

According to Gardner's $(1983,1999)$ theory "Linguistic intelligence" is prevalent in students who can manipulate language both at the semantic and the structural level. "Visual or spatial" is the ability to mould mental models of knowledge. Students with augmented "visual or spatial" capacity need to "see" in order to acquire and handle new information. "Bodily-kinaesthetic intelligence" assists learners to process knowledge through relating physical and mental skills. "Interpersonal intelligence" is indicative of people who need to interact with others, whereas "Intrapersonal" students resort to individual work. "Musical Intelligence" combines knowledge to rhythm and "Logicalmathematical intelligence" is the ability to think critically, make deductions and excel at numbers. Finally, "Naturalistic Intelligence" signifies the necessity to relate knowledge to nature.

The implication of Gardner's $(1983,1999)$ theory on curriculum design is that all these types of intelligence must be embedded in its philosophy and formulation in order to cater for all "frames of mind" and learning styles.

\subsubsection{Crosscurricularity}

Crosscurricularity repudiates the compartmentalisation of knowledge, putting forward the synthesis of school-obtained knowledge which triggers the development of students' critical thinking (Matsaggouras, 2003). Brewster, Ellis and Girard (1992) also highlight the contribution of crosscurricularity to the growth of the learners' potential to learn how to learn, the promotion of their thinking strategies and study skills. Additionally, they stress that crosscurricularity guarantees more continuity of learning throughout the curriculum, which constitutes a prerequisite of learning and reflects the teachers' will. Finally, Karatzia-Stavlioti (2002) claims that a crossthematic curriculum promotes the holistic approach of education in two ways: students are involved in all aspects of the learning process, that is cognitively, socially and affectively, while new components of knowledge are gradually added to the students' overall cognitive and social background.

The significance of crosscurricularity resulted in educational modifications all over Europe prioritising the interdisciplinary component in the design of the national curricula (Karatzia-Stavlioti, 2002).

\subsubsection{Krashen's theory of Second Language Acquisition}

Presenting his second language acquisition theory which is viewed as the most prevailing one concerning acquiring a second language, Krashen (1985) introduced the Natural Order Hypothesis. According to this theory, linguistic structures are acquired in a premeditated array in compliance with an anticipated sequence that eases learning. Translated in the curriculum design context, this implies that the orchestration of the curriculum should pursue a specific sequence so as knowledge is gradually assimilated. 
During the last decade differentiated instruction, that is tuition that is tailored to the pace and needs of individual students, has witnessed great proliferation (Tomlison, 1999, 2001; Valiande \& Koutselini, 2008; Valiande, 2010; Panteliadou \& Filippatou, 2013).

Tomlison (2001) postulates that differentiated instruction is "proactive" (ibid, p. 3) planned to be flexible enough to suit a range of learners' needs. Moreover, she argues that differentiated tuition is student-centered placing the students' needs at the focal point of schooling and offering the learners the opportunity of assuming responsibility of their own growth. Three curricular components must be pondered on, according to Tomlison (2001), that is a) content in the sense of what the students learn, b) process that is how they acquire knowledge and c) product in the form of output which discloses the mastered knowledge so far. In an effort to take this notion a step further and offer equity of educational opportunities for all pupils, Langa and Yost (2007) focus on a more individualised level and introduce three more elements advising decision makers to assess each student's linguistic level, interests and learning profile before deciding on the specification of content, process and product.

Seen in this perspective, there arises the need to restructure and differentiate the curriculum with a view to fine tuning its philosophy and content to the diverse dexterities, preferences and learning styles of all students.

\subsection{Administrative Scope}

From an administrative point of view there are two ways of organising a curriculum: the top-down and bottom-up. A top-down or "specialist" (Graves, 2008, p. 150) process usually involves large-scale curricular reform emanating from high ranking decision makers (Waters \& Vilches, 2001) excluding the end-users of the innovation, that is the teachers and the learners. Informed as this approach as it may be from a pedagogical perspective, it possibly, nevertheless, poses the risk that classroom implementation bears little resemblance to the original curriculum plans. In such a situation, on the one hand, educational authorities blame the instructors for defying curricular modification and on the other hand, teachers feel that administrators are totally ignorant of classroom reality (Graves, 2008). On the contrary, in the bottomup process the triggered innovation of curriculum is the result of the initiative taken by the members of the learning institutions, that is the teachers based on their own and their students' needs. Seen in this vein, "teachers may act with or without the help of an outside change agent" (Markee, 1997, p. 67).

\section{The Greek Educational Context: The National Curriculum}

The Greek national curriculum is fully "centralised" (Nunan, 1982, p. 21) framed by the Ministry of Education and then assigned to the learning institutions of primary and secondary education.

In general, four developmental domains are involved in the devise of a curriculum, namely curriculum planning, specification of ends and means, programme implementation and classroom implementation (O'Brien, 1999, Vol.1, p. 7). As far as the Greek educational setting is concerned, curriculum planning is assigned by the Greek Ministry of Education to a pedagogical institution, which was named Pedagogical Institute (http://pi.schools.gr) until 2011 and is now called Institute of Pedagogical Policy (http://www.iep.edu.gr) along with university experts. The pedagogical institution and the academicians usually specify the ends and means which entail the specification of the objectives of the curriculum and the methods to attain them. The most important prerequisite for the formulation of the general aims and specific objectives of a curriculum is the conduct of needs analysis (West, 1994; Hutchinson \& Waters, 1996). This entails using appropriate techniques and processes so as to gather necessary information about the learners' needs, the teaching milieu and the general educational and social context with the view of charting the proper basis for decision making (Núñezy Bodegas, 2007) about the foundation, content, aims and realisation of the curriculum. Programme implementation comprises of materials writing and teacher training and finally classroom implementation refers to the most necessary components of the whole procedure, that is the teachers and learners. In order for a curriculum to be effective there must exist coherence among its stages and each phase should inform the others (Graves, 2008).

The design of the Greek national curriculum is influenced by the global and national educational, social and cultural changes. Such alterations include globalisation, continuous innovations in diverse scientific fields, especially information technology and the need to enable all citizens to renew their knowledge and skills through life-long learning. Moreover, social and workforce mobility within the European Union has necessitated the promotion of acceptance of otherness. Finally, the necessity to provide equal learning opportunities to all students according to their linguistic, cognitive, emotional and developmental level has been prioritised.

The aforementioned dimensions have led to the formulation of various documentations of the national curriculum with a view to meeting the emerging educational, pedagogical and social needs. These different versions of the Greek curriculum include diverse documents for the individual curriculum of teaching English as a foreign language.

This part described the Greek national curriculum and put forward the necessity for its reconceptualisation following the contemporary educational and social advances. The focus of the next part will shift to the individual curriculum for teaching English as a foreign language. More specifically, the three latest versions, namely 1997-2014, will be presented and commented on.

\section{The Three Latest EFL Versions}

The three last EFL versions are: 1 . The Comprehensive 6-year Curriculum for the Teaching of English $\left(4^{\text {th }}-9^{\text {th }}\right.$ form) (1997), 2. The Crosscurricular Unified Programmes of Study - Individual Curriculum for English (2003) and 3. The Integrated Foreign Languages Curriculum (2011). 
Given the importance of the redefinition of the curricula for teaching English in the Greek state schools following the methodological alterations of the general national curriculum, various studies were conducted concerning their implementation. In an effort to trace similarities and differences Dinas and Tellidou (2007) compare and contrast the curricula for teaching English as a FL in the Greek primary school from 1997- 2002. They conclude by stressing the fact that the educational authorities should ensure that the syllabus and the coursebooks taught in primary education comply with the methodological and educational approaches presented in the curricula. Staikou and Koutalakidou (2007) investigated the crosscurricular programmes of study for teaching English and French in the Greek state primary school with a view to formulating suggestions for a more effective interrelation of these two documents. They revealed that, even though the basic philosophical assumption of the curricula is the crossthematic approach and the promotion of multilingualism, there is no interaction of the two foreign languages. Thus, crosscurricularity is limited to the interrelation of the mother tongue with each foreign language separately. They propose some crosscurricular tasks in order to relate the two foreign languages which include projects, games and pantomime.

Exploring the Integrated Foreign Languages Curriculum (2011), Diamesi (2012) highlights its innovative elements which are: a) it is the first curriculum aspiring to be common for all the foreign languages taught in Greek state school, b) Regarding the teaching of foreign languages, it attempts to abolish the traditional school grades and recommends grades formulated with relevance to the proficiency level of the students according to the Common European Framework of Reference for languages (2001) and c) it urges the foreign language teachers to create their own materials which are appropriate to their students' level and needs rather than rely solely on the coursebook.

Having presented relevant studies concerning the gradual modification of the curriculum for teaching English in the Greek educational setting, an attempt will be made by the present author to elaborate on the three latest EFL versions.

\subsection{Comprehensive 6-year Curriculum for the Teaching of English ( $4^{\text {th }}-9^{\text {th }}$ form)- 1997- 2002: Documentation and Theoretical Assumptions- Version 1}

The design and the documentation of the first curriculum, that is the "Comprehensive 6-year curriculum for the teaching of English $\left(4^{\text {th }}-9^{\text {th }}\right.$ form)" in state schools (Dendrinos et al., 1997) was entrusted by the Greek Ministry of Education to a committee whose members were a University professor, an EFL school advisor, five teachers and a member of the Pedagogical Institute. Thus, it was completely authority-oriented complying with the top-down approach of curriculum design.

The main aim of the curriculum under discussion is to teach learners English in order to contribute to their linguistic growth, cognitive development and social-cultural evolution as pupils and citizens, in their overall socialisation and education.

The curriculum presumes that knowledge is a learning experience (Dendrinos et al., 1997, pp.71- 72) which is the result of a complicated spiral process in which new information is correlated to previously assimilated knowledge and to the students' prior experiences. Seen in this discourse, this curriculum is fully aligned with Krashen's (1985) Natural Order Hypothesis.

In the context of curriculum 1, language is not perceived exclusively as an abstract system but as communicative behaviour expressing meaning. This aspect abides by Widdowson's (1978, p. 3) view about appropriately exploiting language for a communicative purpose. Simultaneously, the English language constitutes a goal in itself meaning that the communicative orientation will not downgrade the focus on form.

Another major goal of the present curriculum is the promotion of autonomous learning by engaging students in experiential, discovery learning (Dendrinos, et al., 1997, pp. 70 -71), participation in the assessment of their progress and acknowledgement of the contribution of their errors to their personal development.

Since, the curriculum under consideration focuses on the communicative approach, prioritises learner independence and aspires to aid learners to absorb the fundamental communicative and linguistic tasks instead of simply amassing the totality of the language, it can certainly be deemed as "pupil-centered".

A first attempt was also made in the current documentation to embed elements of crosscurricularity by advising instructors to draw information from other subjects taught at school and to attribute to the students the role of "an intermediary between monolingual individuals and groups" (ibid, p. 69). Nevertheless, these notions of crosscurricularity and mediation were still in their infancy in the Greek educational system when the first version was under design.

While, the respect of otherness is indisputable in the curriculum (ibid, p. 69), there is no evidence of overt integration of the Multiple Intelligences and differentiated instruction.

\subsection{Crosscurricular Unified Programmes of Study - Individual Curriculum for English (2003-2014)- Version 2}

Major changes took place in the last few decades globally, namely social, cultural, financial, political and technological ones which necessitated the reconceptualisation of education (Government Gazette 303/13-03-03, p. 3733). Access to ever-changing knowledge, computer literacy and life-long learning are of primary significance to individual growth.

In order to avoid social seclusion and educational inequity, the European Union opted for curricula with crossthematic orientation (Karatzia-Stavlioti, 2002) so as to synthesise knowledge from various disciplines and render them more acquirable to all learners. In this vein, the Crosscurricular Unified Programmes of Study were created in 2003 and Individual curricula for each subject were formed. 
The Individual curriculum for English (304/13-03-2003, pp. 4085 - 4113) is also systematically- based on crosscurricularity, serving as a multifaceted method of teaching students, depending upon the collaboration of various disciplines across the curriculum. Students seek for relevant information from diverse school subjects and therefore develop discovery learning, problem-solving, experiential learning and the ability of "learning-how-to learn" (Williams, 1991, p. 226) undertaking the onus of their own learning. As it can be easily seen, this curriculum is student-centered. Furthermore, the Multiple Intelligences are thoroughly capitalised on through the cooperation of the various disciplines. The implications are that all frames of mind are accommodated in teaching English and differentiated instruction is employed since all learning styles are catered for. Additionally, curriculum 2 is compatible with the Natural Order Hypothesis since the continuation of teaching from elementary to secondary school is strongly recommended. This curriculum has an explicit communicative orientation aiming to teach learners English so as to further their dexterity to utilise English in everyday communication situations, in both foreseeable and unanticipated milieux so as to boost their educational and social life in the short-term and simultaneously enable them to handle the future social and professional demands.

The new element relative to curriculum 1 is that language is perceived as not only a means for communication but as a tool for acquiring and processing knowledge from different subject areas. Furthermore, apart from the respect of otherness, the notions of literacy, multilingualism and multiculturalism are put forward (ibid, p. 4085). Last, the role of the student as a mediator (ibid, p. 4087) is further stressed requiring the student to mediate among monolingual individuals and groups with the aim of smoothing communication.

\subsection{Integrated Foreign Languages Curriculum (2011-2014)- Version 3}

The Integrated Foreign Languages Curriculum is the last version of the curricula designed in the Greek educational reality in the last seventeen years. It is common for all foreign languages taught at the Greek state school, namely English, French and German and has been in a pilot stage in certain primary and junior high schools for four years.

The main novelty of this version of the curriculum is its accordance with the proficiency levels of the Common European Framework of Reference for languages (2001), describing the expected proficiency and skills according to levels (i.e. elementary- A1, basic- A2 rather than school grades) complying with specific "can do" statements defined for each level. More specifically, in A2 level the students should be able to: a) understand and produce short, simple every day texts, b) describe their daily routines and provide information about their everyday life -i.e. their house, their family, etc., c) to communicate (in simulation) with speakers who are proficient users of the target language exchanging information about every day issues, and d) to produce orally or written in English a piece of information extracted from a short Greek text.

The aims and content of the curriculum under discussion resulted from various forms of cooperation among experts, inservice teachers, literature review and research concerning the programmes of study of other countries as well as research based on corpus consisting of written texts in foreign languages produced by Greeks rather than native speakers (Dendrinos, 2011 et al., p. 11). Consequently, an attempt was made to apply a less strict top-down approach.

Curriculum 3 focuses on the communicative dimension of teaching the foreign language and attempts to promote students' thinking and socialisation. It promotes literacy whereas the notion of multiliteracies emerges in the form of phonemic, structural, sociosemiotic and critical literacy. Another very important focal point is the evolution of multimodality (ibid,p 20) meaning that the various texts may include not only linguistic but also paralinguistic features such as pictures, videos, charts, maps to mention but a few. In addition, the students should be given enough practice to take advantage of all these elements in their effort to interact with the text. A last novel component is plurilingualism which aims at combining, comparing and contrasting the linguistic codes that an individual acquires.

Furhermore, the significance of mediation is put forward and differentiated instruction is stressed with a view to informing teaching about the individual traits of all students, therefore rendering the curriculum student-centered. Moreover, learner autonomy is promoted through experiential learning and crosscurricularity as well as the Multiple Intelligences is fully taken advantage of.

Finally, the current curriculum definitely complies with the Natural Order Hypothesis by gradually following the students' proficiency levels and exhibiting a unitary dimension in both elementary and secondary education (Dendrinos et al., 2011, p. 10).

\section{Comparison of the three curricular documentations}

Part four presented the three versions of the curriculum for teaching English in the Greek state school (1997- 2014). An attempt will be made in this section to compare and contrast these three documents in order to identify similarities and diversities.

\subsection{Similarities}

There are similarities among the three curricula, the first being their communicative dimension. In addition, socialisation, collaboration, citizenship awareness, opportunities for professional inclusion, expansion of abstract reasoning, use of technology, advancement of experiential learning and discovery of knowledge, which will empower pupils to learn how-to-learn are common features in all three frameworks.

Another common aspect is the assimilation of new knowledge. All three curricula are in favour of gradual accommodation of new information to previously obtained linguistic and mental schemata in connection to the students' needs. 
A last correlation of the three documents is their effort to place the students' needs at the center of their design, to enhance learner independence and to encourage students to use English as mediators so as to ease communication of people from diverse linguistic backgrounds.

Although, some elements of introducing the cooperation among different school subjects arose in the first curriculum, it was the second one which rendered crosscuricularity into its core philosophical assumption. The third version also argued in favour of the benefit of the interdisciplinary cooperation to the advancement of students' opportunities for knowledge and cognitive evolution.

\subsection{Differences}

Even though, the first curriculum accentuated the significance of teaching English to help students respect otherness, the notion of multiculturalism and its contribution to help the students develop tolerance were adequately underlined only in the last two documentations.

Much in the same vein, the first two curricula stressed the importance of literacy but it was the third one that referred to the new kinds of literacy, the tenet of multiliteracies and the notion of multimodality. This orientation of the third version aimed at equipping the learners with innovative techniques in their endeavour to acquire L2 and develop cognitive, metacognitive and linguistic capacities.

Furthermore, the first two documentations have a clear top-down design whereas in the third edition an effort was made to take the teachers' opinion into account in the planning stage. Thus, a more bottom-up approach was followed in the Unified Programmes of Study and what is more, its creators (Foreign languages at school 2011, p. 10) claim that this document is deemed more as a programme of study rather than a preset curriculum giving the teachers the liberty to form their own curriculum according to their teaching situation.

Since differentiated instruction was in the incubating stage when the first edition was formulated, it was excluded from its goals. Nevertheless, the second and the third curricula fully incorporated the importance of tiered tuition to suit the students' needs and promote the Multiple Intelligences that the learners display. The culmination of differentiated instruction lies in the recommendation of the pilot edition to group and teach students according to proficiency levels providing them with the opportunity to learn the $\mathrm{L} 2$ at their own pace and needs.

Finally, a major differentiation of the third version is its ambition to connect the teaching of L2 to the acquisition of the $\mathrm{KPg}$ - the state certificate of language proficiency.

This orientation seems to be in line with the Greek society's hidden curriculum (O' Brien, 1999), that is the prevailing assumptions and beliefs about learning a foreign language. Greek parents seem to be totally exam-oriented (Nikolaou, 2004) downplaying the communicative, cognitive and social aspects of learning a foreign language. Instead, they strongly believe that a language certificate is an indispensible qualification for their children's career advancement restricting the learning of an $\mathrm{L} 2$ to a material rather than cognitive spectrum.

\section{Concluding remarks}

A careful exploration of the three curricula revealed that all three documents shared the communicative orientation, crosscurricularity and the idea of gradual acquisition of knowledge by utilising previous experience and applying recycling of information. Moreover, they advocated learner-centeredness, learner autonomy, respect of otherness, students' metacognitive development and student mediation with the aim of rendering the communication of people from diverse linguistic origin easier.

Furthermore, they gradually embraced the emerging pedagogical and methodological innovations, namely differentiated instruction, multiliteracies, multimodality and multiculturalism and certification concerns. Additionally, the use of information technology has been smoothly incorporated.

Despite the gradual development of the curriculum versions following the contemporary developments in education and information technology, there are still areas that could be improved. Therefore, the following suggestions for improving the content and aims of an EFL curriculum are proposed:

a. A curriculum is regarded as coherent when there is harmonious transition among its four stages- planning, specification of ends and means, programme implementation, classroom implementation - and each level gives feedback to and also receives data from the previous and the next one. This means that decision makers should take this stance into consideration during the design of a curriculum if they desire to achieve maximum results.

$b$. Pedagogical and methodological innovations originating from the global experience should be carefully pondered on, piloted and maybe fine-tuned to the local context so as to be prudently integrated in a national curriculum. Only in this way, will they aspire to succeed in the Greek state school reality.

Finally, as Maciel $(2008$, p. 8) claims, decisions for curricular innovation may be instigated by numerous stimuli (such as adoption of innovations, concerns with classroom practice - (ibid, p. 2), the aim and efficacy of which must be fully understood by all the involved members. Only such a procedure, will guarantee negotiation of the engaged stakeholders and cooperation among them which will ensure the success of a newly-designed curriculum to the benefit of the students. 


\section{References}

Bell, D. (2007). Do teachers think that methods are dead? ELT Journal 61/2, p.143.

Brewster, J., Ellis, D. \& Girard, D. (1991). The primary English teacher's guide. Harmondsworth: Penguin.

Brown, H. D. (2002). 'English language teaching in the "post-method" era: Toward better diagnosis, treatment, and assessment' in J. C. Richards and W. A. Renandya (eds.). Methodology in Language Teaching: An Anthology of Current Practice. Cambridge: Cambridge University Press.

Brumfit, C. (1984). Function and structure of a state school syllabus for learners of second or foreign languages with heterogeneous needs" General English Syllabus Design ELT Documents 118. Oxford: Pergamon Press and British Council, pp 75-81.

Bruner, J. (1988). On teaching thinking: an afterthought in Richardson K. \& Sheldon, S. (1988 eds) Cognitive development to adolescence. Hove: Psychology Press Publishers and the Open University.

Council of Europe. (2001). Common European framework for reference for languages: Learning, teaching, assessment. Cambridge: Cambridge University Press.

Dendrinos, B., Triantafilou, T., Tagglidis, T., Kosovitsa, C., Kinigou, I., Liarou, E., Mouzekiti, A., \& Sepirgioti, M. (1997). Comprehensive 6 year curriculum for the teaching of English $\left(4^{\text {th }}-9^{\text {th }}\right.$ form) Athens: OE $\Delta \mathrm{B}$.

Gardner, H. (1983). Frames of mind: The theory of Multiple Intelligences. New York: Basic Books.

Gardner, H. (1999). Intelligence reframed: Multiple Intelligences for the 21st century. New York: Basic Books.

Graves, K. (2008). The language curriculum: A social contextual perspective.Language Teaching 41/2, pp. 147-181. Cambridge University Press. doi:10.1017/S0261444807004867.

Hall, D. R. \& Hewings, A.(eds.) (2001). Innovation in English language teaching: A reader. London: Routledge.

http://pi.schools.gr.

http://www.iep.edu.gr

Hutchinson, T. \& Waters, A. (1996). ESP A learning centred approach. Great Britain: Cambridge Universtiy Press

Krashen, S. D. (1985). The Input Hypothesis: Issues and implications. London: Longman.

Kumaravadivelu, B. (1994). 'The postmethod condition: (e)merging strategies for second/foreign language teaching'. TESOL Quarterly 28/1: 27-47.

Langa, M. A., \& Yost, J. L. (2007). Curriculum mapping for differentiated instruction, $k$-8. Thousand Oaks, California: Corwin Press.

Maciel, R. F. (2008). Curricular innovation in language teaching: implication for teacher development. X Seminário de Lingüística Aplicada. UFBA: Salvador.

Markee, N. (1997). Managing curricular innovation. Cambridge. Cambridge: University Press.

Nunan, D. (1988). The learner-centered curriculum. Cambridge: Cambridge University Press.

Nunan, D. (1989). Designing tasks for the communicative classroom. Cambridge: Cambridge University Press.

Nunan, D. (2004). Task-based language teaching. Cambridge: Cambridge University Press.

Núñezy Bodegas, I. D. (2007). From curriculum to syllabus design: The different stages to design a programme. In Memorias del III Foro Nacional de estudios en lenguas: Fonael. ISBN 978-968-9308-13-3.

O’Brien, T. (1999). Course design and evaluation. Vol. 1. Patras: Hellenic Open University.

Panteliadou, S. \& Philippatou, D. (2013 eds). Differentiated instruction. Athens: Pedio.

Pantaleoni, L. (1991) "L2 syllabusing at primary level: the Italian perspective' in Brumfit et al., (eds) Teaching English to young learners. London: Collins ELT.

Prabbu, N. S. (1990). There is no best method-Why? TESOL Quarterly 24/2, pp. 161- 172.

Richards, J. C. 1990. 'Beyond methods' in J. C. Richards (ed.). The Language Teaching Matrix. Cambridge: Cambridge University Press.

Swan, M. (1985). A critical look at the Communicative approach. ELT Journal 39/2, p 87.

Tomlinson, C. (1999). The differentiated classroom: Responding to the needs of all learners. Alexandria, VA: Association for Supervision and Curriculum Development.

Tomlinson, C. A. (2001). How to differentiate instruction in mixed-ability classrooms. (2nd Ed.) Alexandria, VA: ASCD.

Valiande, S. \& Koutselini, M. (2008). Differentiation instruction in Mixed Ability classrooms, the whole picture: Presuppositions and Issues. Paper presented at the annual meeting of the International Academy of Linguistics, Behavioral and Social Sciences. Newport Beach, California.

Valiande, S. (2010). Differentiated Teaching in Mixed Ability Classrooms / Learning Processes and Effectiveness. Unpublished doctoral dissertation, University of Cyprus, Nicosia, CY. (In Greek). ISBN 978-9963-689-91-0. 
Waters, A. \& Vilches, M. L. C. (2001). Implementing ELT innovations: A needs analysis framework. ELT Journal 55/2, pp. 133-141.

West, R. (1994). Needs analysis in language teaching. Language Teaching 27/1, pp. 1-19.

White, R. (1988) The ELT curriculum: Design, innovation and management. Oxford: Basil Blackwell.

Widdowson, H. G. (1978) Teaching language as communication. Oxford: Oxford University Press.

Williams, M. (1991). A framework for teaching English to young learners in Brumfit et al., (1991 eds) Teaching English to young learners. London: Collins.

\section{Greek References}

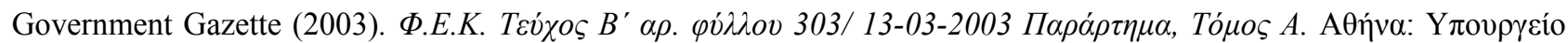

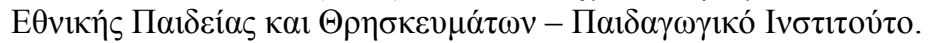

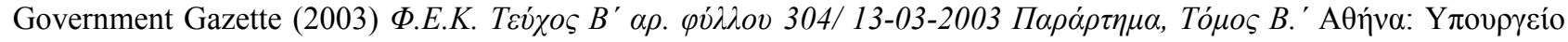

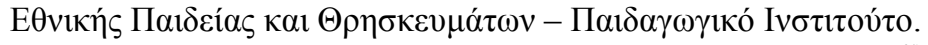

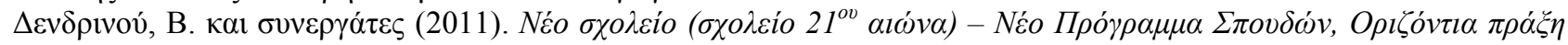

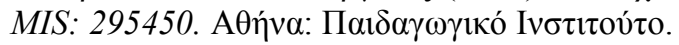

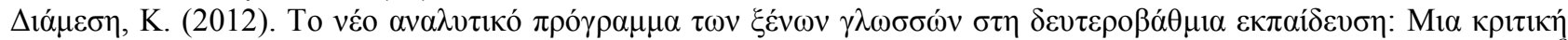

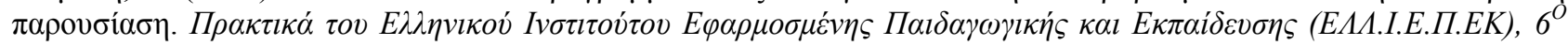

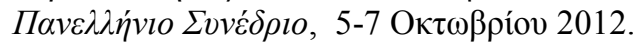

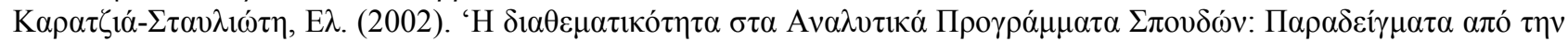

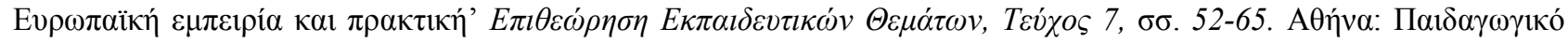

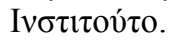

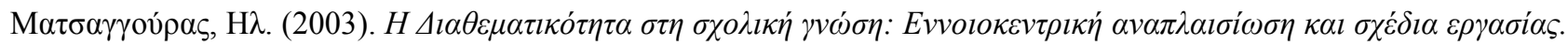

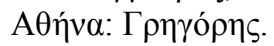

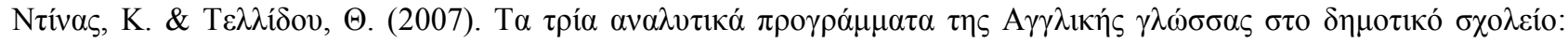

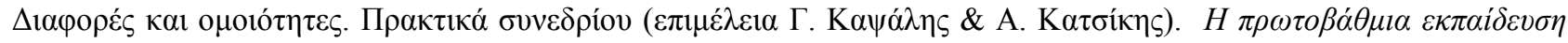

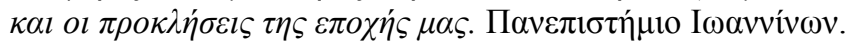

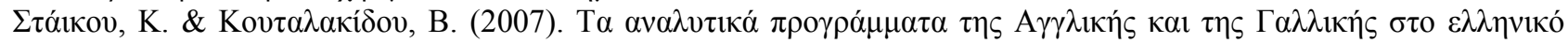
$\delta \eta \mu o ́ \sigma 10 \quad \sigma \chi о \lambda \varepsilon i ́ o . \quad A v \alpha \kappa \tau \eta ́ \theta \eta \kappa \varepsilon \quad \alpha \pi$ ó http://ipeir.pde.sch.gr/educonf/2/02/AnalitikoProgramma/staikoukoutalakidou/staikou-koutalakidou.pdf 10-10-2014.

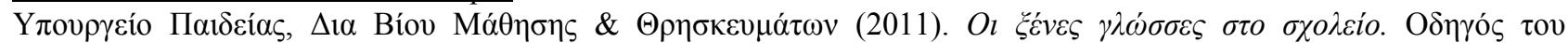

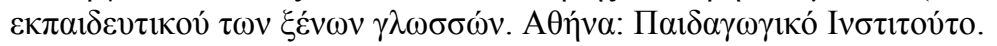

